\title{
Utfordrende atferd hos personer med demens er krevende for sykepleiere
}

Sykepleiere må kunne håndtere utfordrende atferd hos personer med demens. Da trenger de kjennskap til pasienten, kunnskap om demens og forståelse for atferd som kommunikasjonsuttrykk.

\section{Marianne Simonsen}

Fagansvarlig for institusjoner

Avdeling for helse og omsorg, Hammerfest kommune

\section{Ann Karin Helgesen}

\section{Professor}

Institutt for sykepleie, helse og bioingeniørfag, Høgskolen i Østfold og Institutt for helse- og omsorgsfag, UiT Norges arktiske universitet

Demens

Utfordrende atferd

Sykepleien 2021109 (86889) (e-86889)

DOI: 10.4220/Sykepleiens.2021.86889

\section{Hovedbudskap}

For sykepleiere er kjennskap til pasienten, kunnskap om demens og forståelse for atferd som kommunikasjonsuttrykk grunnleggende elementer for å kunne tilpasse tilnærmingen til utfordrende atferd hos personer med demens.

Kjennskap, kunnskap og forståelse gjør det mulig å være bedre forberedt på det uforutsigbare i møte med pasienten. Hyppige situasjoner med utfordrende atferd kan være krevende for sykepleiere. De erfarer at det er spesielt krevende når de ikke blir satt i posisjon til å hjelpe. 
I denne artikkelen presenterer vi resultater fra en studie der vi intervjuet sykepleiere på sykehjem som jobber på styrket skjermet enhet med personer med demens som har utfordrende atferd. Hensikten med studien var å få kunnskap om sykepleiernes erfaringer med denne pasientgruppen.

\section{Metode}

Studien har en kvalitativ tilnærming, og datainnsamlingen foregikk ved intervjuer. Inklusjonskriteriene for å kunne delta i studien var bachelor i sykepleie og minimum tre års erfaring som sykepleier innenfor demensomsorg.

Vi gjennomførte intervjuene i to forsterkede skjermede enheter i Nord-Norge. Fire sykepleiere ble intervjuet. Dataene analyserte vi ved hjelp av systematisk tekstkondensering (1).

Studien er godkjent av Norsk senter for forskningsdata (referansenummer 652128). Sykepleierne ga skriftlig informert samtykke etter å ha blitt kjent med studiens formål og hadde mulighet til å trekke seg fra studien uten at det ville få konsekvenser for dem.

\section{Resultater}

\section{Sykepleierne må bli kjent med pasienten}

Sykepleierne fremhevet at pasientens livshistorie er den viktigste redskapen de har i møte med personer med demens som har utfordrende atferd. Ved å bruke livshistorien aktivt kan de bidra til å skape trygghet for personen med demens gjennom å bekrefte hvem vedkommende er.

Livshistorien kan også brukes som avledning $\mathrm{i}$ utfordrende situasjoner. Tiltaksplaner er også noe sykepleierne trakk frem som positivt. De fortalte at tiltaksplaner kan danne et grunnlag for at personalet har samme måte å møte pasientene på, hvilket skaper trygghet og forutsigbarhet. 
Like viktig som tiltaksplaner er observasjonene som gjøres i møte med pasienten: «Det er som å bli kjent med nye mennesker, vi må være sammen med dem over tid, og så må vi se hvordan de responderer. Vi må være sammen med dem for å lære dem å kjenne, for å se den endringen $\mathrm{i}$ blikket, for å se den endringen $\mathrm{i}$ kroppsbevegelsen, om de er knapp eller om de er myk. Vi må se på måten de tygger på, altså det er alt» (sykepleier 1).

\section{«Livshistorien kan også brukes som avledning i utfordrende situasjoner.»}

Sykepleierne beskrev at det er avgjørende å ha forståelse for hva demens er, hvordan sykdommen utvikler seg, og hvilke konsekvenser det kan gi for pasienten.

De fremhevet nødvendigheten av å ha kunnskaper om atferd som kommunikasjonsuttrykk, det vil si at atferd må forstås som et uttrykk for et underliggende budskap som pasienten ikke er i stand til å formulere verbalt: «Raskt endret atferd har som oftest en bakenforliggende årsak. Da må vi forske, da må vi bruke eliminasjonsmetoden» (sykepleier 1).

Sykepleierne beskrev en eliminasjonsmetode der de utelukker at det er somatiske plager som ligger til grunn for den endrede atferden. De fremhevet at å gi beroligende medikamenter når en person fors $\varnothing$ ker å kommunisere noe som plager dem, kan overskygge det som faktisk er årsaken til at atferden oppstår.

Dersom den somatiske eliminasjonsmetoden ikke forklarer atferden, vurderer sykepleieren om atferden kan være uttrykk for noe annet, for eksempel en annerledes virkelighetsoppfattelse: 
«Fullt forståelig at hun fru Hansen klatrer ut av vinduet dersom hun tror barna er alene hjemme, selvfølgelig. Hadde det vært meg som hadde en opplevelse av at ungene var alene hjemme og at du hadde stengt meg inne, jeg hadde jo smurt deg rett ned. Det er jo helt, helt forståelig. Hvis noen da i tillegg hadde gitt meg en kopp kaffe, hadde jo vært helt idiotisk. Ta nå heller og hjelp meg hjem» (sykepleier 1).

\section{Kartlegging brukes i krevende situasjoner}

For å få en oversikt over den utfordrende atferden bruker pleiepersonalet ulike metoder for kartlegging. Ifølge sykepleierne benyttes ikke kartlegging systematisk. Det er først når de ikke klarer å finne årsaken til atferden at kartlegging utføres. Mest benyttet er døgnregistreringsskjema, også kalt mengdekartlegging.

Skjemaet kan benyttes for å kartlegge ulike typer atferd og symptomer gjennom døgnet. Det kan belyse hvor ofte disse inntreffer, hvor lenge de varer, hvilke situasjoner de oppstår i, når på døgnet de eventuelt endres, og liknende.

En av sykepleierne fortalte at de bruker situasjonskartlegging i avdelingen. Det gjør det lettere å finne årsaken til at atferden oppstår, og det blir mulig å se et mønster.

Ved situasjonskartlegging kartlegger sykepleierne hva som skjedde i forkant av situasjonen, selve situasjonen og hvordan den ble løst. Døgnregistreringen og situasjonskartleggingen varer i cirka en til to uker før materialet analyseres.

\section{Tilnærmingen må tilpasses hver enkelt}

Sykepleierne fortalte at det viktigste er å tilpasse tilnærmingen til hver enkelt pasient. Uavhengig av om det gjelder forebygging eller å dempe utfordrende atferd, er det viktig å formidle ro i situasjonen: 
«Jeg går sakte mot pasienten, jeg er rolig og har lavt toneleie. Etter hvert går jeg nærmere med omsorg, da stryker jeg kanskje litt på pasienten sin skulder. Jeg bruker korte setninger, sørger for at pasienten forstår at jeg er her for å hjelpe» (sykepleier 3).

Sykepleierne er bevisst på sitt eget kroppsspråk i møte med pasientene, og de fortalte at det er viktig å fremstå som trygge i møter der atferden er utfordrende. Nye og uerfarne pleiere kan gjøre situasjoner mer utfordrende:

«Dersom noen i personalet ikke vet hva de skal gjøre og blir redd eller usikker i møte med en pasient som selv føler seg utrygg, så kan situasjonen bli enda verre for pasienten. Da blir ofte atferden verre» (sykepleier 2).

Ulike tiltak iverksettes i møte med en utagerende pasient. Sykepleierne fortalte at det er vesentlig å vise forståelse og bekrefte at man ser at personen er lei seg, for så å gi trøst eller å vise ydmykhet når personen blir agitert. En annen løsning er å gå ut av situasjonen for så å fors $\varnothing$ ke på nytt igjen eller bytte pleier.

\section{«Bruk av medikamenter må vurderes nøye, og en helhetsvurdering må legges til grunn.»}

Bruk av medikamenter må vurderes nøye, og en helhetsvurdering må legges til grunn: «Det handler om: Hvorfor gir du medisiner? Er det for at pasienten skal få det bedre, at den skal få det lettere, for at den skal få bedre ro til å spise, for at pasienten skal kunne få muligheten til å glede seg over en tur ut eller hva det måtte være, så tenker jeg at det er på sin plass. Hvis tanken er at det er vanskelig for oss, da er vi helt på villspor. Det er pasienten vi må ha i fokus» (sykepleier 1).

Dersom pasienten er veldig agitert, kan sykepleierne imidlertid vurdere å gi en tilpasset dose beroligende medisin slik at pasienten får roet seg. Da kan pleierne komme i en bedre posisjon for å kunne hjelpe. 
Sykepleierne fortalte at deres egen tilnærming ofte er årsaken til at den utfordrende atferden oppstår. Andre ganger kan det være umulig å forutse, og sykepleierne må derfor være føre var. I tilnærmingen må de være forberedt på at en plutselig atferdsendring kan forekomme. Det gjelder å være observant på pasientens kroppsspråk og ansiktsuttrykk.

Plutselige atferdsendringer kan oppstå som en følge av høy lyd eller andre overraskelsesmomenter:

«Vi skal ta en risikovurdering hver gang vi skal møte en pasient som kan ha en atferd i form av fysisk utagering. Vi skal tenke hva det er jeg kan møte her, hvordan stiller jeg meg, hvordan har jeg håret, har jeg noe som er løst slik at jeg kan bli kvelt. Jeg er alltid imellom når vi er hos de krevende pasientene, jeg vet alltid hvor døren er, jeg har alltid ryggen mot veggen og vet alltid hvor pasienten er» (sykepleier 1).

\section{Personalet opplever utfordrende atferd daglig}

Sykepleierne fortalte at de opplever situasjoner med utfordrende atferd daglig. Det aller mest utfordrende er imidlertid ikke atferden i seg selv, men å ikke komme i posisjon til å hjelpe.

«Atferden var så vekslende. Personen ble så sint på meg og ville slå meg og mine kollegaer, det var ikke det som var vanskelig. Det som var vanskelig, var at vi ikke klarte å hjelpe vedkommende i hans frustrasjon og sinne. Vi klarte ikke å få tak på hva det var, vi klarte ikke å trygge han» (sykepleier 1).

Sykepleierne beskrev at det er vanskelig å se hvor vondt noen av pasientene har det følelsesmessig. Det er utfordrende å ikke strekke til for å hjelpe dem i disse situasjonene. Sykepleierne fortalte at det gjør noe med deres egne følelser. De er usikre på hvordan det vil bli å møte pasienten etter ubehagelige situasjoner. 
«Det var liksom fra det ene til det andre, sånn

følelsesmessig så var jo jeg oppkavet og bare ‘aåååh, herregud', for jeg var jo rød rundt halsen og hadde merker etterpå, så det var jo ordentlig kvelertak. Så det var kanskje litt utfordrende for meg selv, da, at jeg måtte skifte situasjon, så du kan ikke la følelsene liksom ta overhånd» (sykepleier 4).

«Det er også det at man klarer å skille den utfordrende atferden, det er viktig. At du ikke får et sånn horn i siden til pasienten. Det er viktig at man skaper en ny dag» (sykepleier 4).

\section{«Deltakerne trakk frem at det er viktig å støtte hverandre $i$ hverdagen, og at refleksjon kan bidra til å forstå atferden.»}

Sykepleierne uttrykte at de har gode rutiner for refleksjon på avdelingene der de jobber. Refleksjonen er ikke satt i system, men skjer der og da når de føler at behovet er der. Innholdet i refleksjonen varierer. Det kan dreie seg om årsakene til en atferd eller at en i personalgruppen har opplevd en utfordrende situasjon.

Deltakerne trakk frem at det er viktig å støtte hverandre i hverdagen, og at refleksjon kan bidra til å forstå atferden: «Vi er veldig flinke til å dele erfaringene våre med hverandre. Dersom noen får til en god samhandling med en pasient som andre har utfordringer med, deler vi erfaringene med hverandre. Vi spiller hverandre gode» (sykepleier 3).

«Det å gjennomgå en situasjon med kollegaer i etterkant kan hjelpe meg med å forstå hva jeg kanskje gjorde galt i tilnærmingen, som gjorde sånn at atferden forverret seg» (sykepleier 4).

Sykepleierne beskrev at refleksjon kan være til hjelp for å bedre eventuelle negative holdninger til pasientene og er en nødvendighet for å takle arbeidet. 


\section{Diskusjon}

Studiens resultater viser at god kjennskap til pasienten er avgjørende for å lykkes med samhandlingen.

Sykepleierne beskrev tiltaksplaner som positivt, da disse kan bidra til at personalet møter personen mest mulig likt, og det skaper trygghet og forutsigbarhet.

Kjennskap til pasienten var også en av faktorene som gjorde det mulig å komme i posisjon til å hjelpe. Sykepleierne fremhevet nødvendigheten av å ha personen i fokus og ha kunnskap om livshistorien. Gjennom bruk av livshistorier kan sykepleierne se personen med demens som en hel person i stedet for en «dement pasient» (2).

\section{«Gjennom bruk av livshistorier kan sykepleierne se personen med demens som en hel person i stedet for en 'dement pasient'.»}

I tillegg til kjennskap om pasienten fortalte sykepleierne at det er nødvendig å ha kunnskap om demens og atferd som kommunikasjonsuttrykk for å kunne ha en personsentrert tilnærming (2-4).

Studier viser at en personsentrert tilnærming kan være gunstig i møte med personer med utfordrende atferd (5). Ifølge Helsedirektoratet (6) skal det tilbys miljømessige og psykososiale tiltak basert på personsentrert omsorg og behandling som førstevalg.

\section{Det kan bli synsing uten systematisk kartlegging}

Studien viser at sykepleierne observerer og vurderer pasientenes kroppsspråk kontinuerlig. Kartleggingsverkt $\varnothing y$ brukes i liten grad når atferden endrer seg. Systematisk kartlegging, identifisering og en nøyaktig beskrivelse av utfordrende atferd hos personer med demens er helt sentralt for å kunne forstå og iverksette behandling på en best mulig måte (7). 
Uten systematisk kartlegging og mangelfull

dokumentasjon kan det bli mye synsing blant

pleiepersonalet, noe som kan gi ulik forståelse og

oppfatning av hvorfor den utfordrende atferden

oppstår, og hvilke tiltak som bør igangsettes $(8,9)$.

Selv om ikke sykepleierne benyttet

kartleggingsverktøyet, satte de i gang kartlegging for å finne årsaken til atferdsendringen. Er det en somatisk

tilstand som ligger til grunn, eller er det en annen virkelighetsforståelse av situasjonen?

Rokstad hevder at personer med demens ofte kan ha en annen virkelighetsoppfatning som er preget av hendelser fra tidligere i livet, enn de andre som er til stede i situasjonen (9).

\section{Pleiernes tilnærming kan være en årsak}

Et interessant resultat er at pleieres tilnærming ofte er årsaken til at den utfordrende atferden oppstår. Sykepleierne fortalte at det er essensielt å vise trygghet overfor pasienten.

Dersom pleiepersonalet ikke er godt forberedt på det uforutsigbare som kan skje i samhandlingen, og ikke vet hva de skal gjøre i situasjoner der atferden er utfordrende, kan situasjonen eskalere. Dette kan ofte skje dersom de ansatte er nye og uerfarne.

Faktorer knyttet til miljøet personen befinner seg i, samt samhandlingen med helsepersonell og pårørende, viser seg imidlertid ofte å innvirke på atferden (3). Dessverre preges eldreomsorgen både nasjonalt og internasjonalt av utfordringer knyttet til bemanning, kunnskap og kontinuitet i personalgruppen $(10,11)$, noe som kan ramme tilbudet til personer med demens og utfordrende atferd.

Refleksjon med kollegaer kan være til hjelp 
Et viktig, men ikke overraskende resultat var at hyppige situasjoner med utfordrende atferd kan være krevende for sykepleierne å forholde seg til. Det aller mest utfordrende er imidlertid ikke atferden i seg selv, men at pleierne ikke kommer i posisjon til å hjelpe. Dette er verdt å løfte til diskusjon i ledergrupper og personalgrupper på sykehjem.

Hva kan vi gjøre for at pleiepersonalet skal komme i en bedre posisjon til å hjelpe personer med utfordrende atferd? Hva skjer egentlig hvis vi som sykepleiere stadig erfarer å komme til kort? I verste fall kan følelsen av utilstrekkelighet i arbeidet føre til lav jobbtilfredshet, utbrenthet og søk etter annet arbeid $(12,13)$.

Det kan tenkes at det å reflektere sammen med kollegaer kan bidra til at møte med personer med utfordrende atferd kan bli noe enklere å håndtere. Resultatene fra denne studien belyser imidlertid at refleksjonsarbeidet ikke er satt i system, men skjer der og da når det er behov for det. Ved slik «ad hocrefleksjon» kan det være en fare at man oppsøker personer som gir st $\varnothing t t e$, men ikke n $\varnothing$ dvendigvis utfordrer.

Profesjonell og systematisk refleksjon og veiledning kan på en helt annen måte bidra til en dypere forståelse for hvordan det faglige og det personlige påvirker en selv og situasjonen (14). For at refleksjon og veiledning skal kunne bli en etablert del av sykepleiepraksisen, må tiltaket forankres i ledelsen (15).

Det er mulig at innføring av profesjonell og systematisk refleksjon og veiledningsarbeid kan bidra til å sette helsepersonalet bedre i posisjon til å hjelpe personer med demens og utfordrende atferd. 
Ved å få mulighet til å sette ord på egne reaksjoner og følelser som kan oppstå når man møter utfordrende atferd, blir man mer bevisst på sin egen rolle i samhandlingssituasjonen. En slik bevissthet kan forhåpentligvis bidra til at det sjeldnere er pleiernes tilnærming som er årsaken til at den utfordrende atferden oppstår.

\section{Referanser}

1. Malterud K. Kvalitative metoder i medisinsk forskning: en innføring. 3. utg. Oslo:

Universitetsforlaget; 2011.

2. Grøndahl VA, Persenius M, Bååth C, Helgesen AK. The use of life stories and its influence on persons with dementia, their relatives and staff - a systematic mixed studies review. BMC Nurs. 2017;16(1):28. DOI: 10.1186/s12912-017-0223-5

3. Lichtwarck B, Myhre J, Goyal AR, Rokstad AMM, Selbaek G, Kirkevold $\varnothing$, et al. Experiences of nursing home staff using the targeted interdisciplinary model for evaluation and treatment of neuropsychiatric symptoms (TIME) - a qualitative study. Aging Mental Health. 2018;(8):966-75. DOI: $\underline{10.1080 / 13607863.2018 .1464116}$

4. Harris U, Jönsson I, Fagerström C. A case study in Sweden: the need for person-centred methods in the care of dementia patients with severe aggressive behaviour. I: Garcia D, Archer T, Kostrezewa R, red. Personality and brain disorders. Cham: Springer; 2019. S. $145-59$.

5. Wang G, Gong H, Albayrak A, van der Cammen TJM, Kortuem G. Personalising management of behavioural and psychological symptoms of dementia in nursing homes: exploring the synergy of quantitative and qualitative data. BioMed Research International. 2020;1-16. DOI: 10.1155/2020/3920284 
6. Helsedirektoratet. Demens. Nasjonal faglig retningslinje. Oslo: Helsedirektoratet; 2020.

Tilgjengelig fra:

https://www.helsedirektoratet.no/retningslinjer/demen s (nedlastet 07.09.2021).

7. Mæland MJ, Joa I, Testad I. Agitasjon og funksjon i stell. Førekomst og samanheng hos personar med demens. Sykepleien Forskning. 2013;8(3):232-40. DOI: $\underline{10.4220 / \text { sykepleienf.2013.0092 }}$

8. Melander C, Sävenstedt S, Olsson M, Wälivaara BM. Assessing BPSD with the support of the NPI-NH: a discourse analysis of clinical reasoning. Int Psychogeriatr. 2018;30(4):581-9. DOI: $\underline{10.1017 / \mathrm{S} 1041610217002009}$

9. Rokstad AMM. Se hvem jeg er! Personsentrert omsorg ved demens. Oslo: Universitetsforlaget; 2014.

10. Gaudenz C, De Geest S, Schwendimann R, Zúñiga F. Factors associated with care workers' intention to leave employment in nursing homes: a secondary data analysis of the Swiss nursing homes human resources project. J Appl Gerontol. 2019:38(11):1537-63. DOI: $10.1177 / 0733464817721111$

11. Lohne V, Høy B, Lillest $\varnothing$ B, Sæteren B, Heggestad AKT, Aasgaard T, et al. Fostering dignity in the care of nursing home residents through slow caring. Nursing Ethics. 2017;24(7):778-88.

12. McCormack B, Dewing J, McCance T. Developing person-centred care: addressing contextual challenges through practice development. J Issues Nurs. 2011;16(2):3.

13. Helgesen AK, Fagerli LB, Grøndahl VA. Healthcare staff's experiences of implementing one to one contact in nursing homes. Nurs Ethics. 2020;27(2):505-13. DOI: $10.1177 / 0969733019857775$ 
14. Woodhead EL, Northrop L, Edelstein B. Stress, social support, and burnout among long-term care nursing staff. J Appl Gerontol. 2016;35(1):84-105. DOI: $\underline{10.1177 / 0733464814542465}$

15. Driscoll J, Stacey G, Harrison-Dening, K, Boyd C, Shaw T. Enhancing the quality of clinical supervision in nursing practice. Nursing Standard. 2019;34(5):435O. DOI: $\underline{10.7748 / \text { ns.2019.e11228 }}$ 